\title{
A Pragmatic Approach to Development of an Undergraduate Construction Curriculum in Trenchless Technology
}

\author{
Virendra K. Varma, Mohammad Najafi \\ Missouri Western State College
}

\begin{abstract}
Although trenchless technology has become an economically viable alternative to open-cut construction, the schools of civil and construction engineering are generally lagging behind in providing instruction on trenchless technology to our undergraduate students. There is a lack of knowledge about the role of trenchless technology in dealing with our underground infrastructure problems, and a general unawareness among the design and construction professionals. The fundamentals of trenchless technology are multidisciplinary in nature; hence the field of trenchless technology can be taught at the undergraduate level. This paper addresses a multi-disciplinary approach to development of undergraduate construction curriculum in trenchless technology with instruction spanning the fields of soil mechanics, hydraulics, construction specifications, contract administration, etc. The authors have found that building on the infrastructure of the existing construction curriculum, and making modifications to the curriculum as you go along, is the most practical approach to teaching the fast developing subject matter of trenchless technology.
\end{abstract}

\section{INTRODUCTION}

The demand for improved quantity and quality of community services such as utilities and communications has placed an ever increasing burden on planning, engineering, installing, and maintaining these services. According to a recent study ${ }^{1}$, some 800,000 miles of corroded and leaking wastewater systems are causing environmental problems. It is estimated that approximately 200,000 miles of pipelines are in need of immediate repair or replacement. It is also estimated that approximately $3 \%$ of the existing systems are being added to this need annually. ${ }^{1}$ Trenchless technology techniques offer an alternative for these situations in many cases. $^{2}$

Trenchless technology methods by definition include all methods of installing or rehabilitating underground utility systems with minimum disruption of the surface. Trenchless technology methods have inherent advantages over conventional dig-up and install, or dig-up and replace/repair methods. These advantages include: ${ }^{3}$

p Trenchless technology methods minimize disturbance to the existing environment, traffic, or congested surface or under surface areas. 
p Trenchless technology methods are more suitable for difficult underground conditions, such as, high water table and unstable soils.

p Trenchless technology methods require less exposed working area, therefore, they involve less risk for both workers and the community.

p Trenchless technology methods minimize damage to pavements and disturbances to other utilities. The life expectancy of pavements was observed to have been reduced by up to $40 \%$ by pavement cuts. ${ }^{4}$

b Trenchless technology methods provide less interference with existing utilities and environment, providing opportunities for greater construction productivity.

p Trenchless pipeline rehabilitation methods utilize the host pipeline, therefore, surrounding soils will not be disturbed which would otherwise further the pipeline settlement. This minimizes the need for spoil removal, toxic disposal, and therefore, is more environmentally friendly.

The successful planning, design and execution of underground construction for conduits, pipelines and utilities ultimately depends on people who know how and when to bring the particular pieces of knowledge or skills to bear on the projects. The objectives of this paper are to recognize additional educational needs and to identify strategies for meeting these needs. At the outset, it is important to recognize two key points: ${ }^{5}$

1. Most of the trenchless technology methods have been in existence less than 15 years. ${ }^{6,7,8,9}$

2. The trenchless technology methods which are currently considered unconventional have not generally been included in the undergraduate civil engineering or construction technology education or the textbooks used in such education.

\section{THE TARGET AUDIENCE FOR EDUCATION AND TRAINING}

The audience for trenchless technology education can be divided into four segments, each with different needs. First, there are the users of the utility systems, such as the city engineers, utility owners, and public works officials. Trenchless methods will not usually be considered as an option for new or remedial construction unless these individuals are knowledgeable about trenchless technology and its applications. Second, there are the practicing engineers who must design, evaluate constructibility and do value engineering studies; estimate costs, and prepare the contract documents. The design engineers are either on the in-house staff of the utility owners or work with a consulting engineering firm. 
The third audience is the construction manager or superintendent who works for a specialty or general contractor with trenchless construction capabilities. This audience has largely learned its trenchless technology skills on the job, but more and more individuals are entering this field with degrees in civil engineering or construction technology. The needs of these professionals include knowledge of equipment, contract administration, codes, construction contracts and techniques, soil mechanics, fluids and hydraulics, time and cost factors, estimating, cost engineering, and safety. Since the above three groups are usually civil engineering or engineering technology graduates, the best opportunity to reach future decision makers is through civil engineering or technology undergraduate curriculums. The prospective professionals in these areas are the targeted audience of this paper.

The fourth audience is the machine operator, the skilled foreman or technician who makes things happen in the field. Their educational needs relate to machine operation and maintenance; on the job experience with different types of underground and project conditions; early recognition of operational problems and their diagnoses; and safety and record keeping. Traditionally, these people have been trained on the job by manufacturers and contractors.

\section{OBJECTIVES OF CIVIL/CONSTRUCTION EDUCATION}

The undergraduate education in engineering disciplines, whether it be civil, mechanical, or construction, requires laying the foundation for the engineering fundamentals in basic and engineering sciences in addition to building the strength of our students in a particular technical specialty area. The civil and construction engineering curricula must provide a responsive and evolving curriculum. It must emphasize a well-planned general studies core and a relevant state-of-the-art sequence of major courses. Learning (and teaching) is to be viewed as a team process requiring the dedication of the students and the caring, informed guidance of wellqualified faculty in a mutual pursuit of knowledge. Team-teaching among faculty experienced in the applications of current technology is essential to delivery of a successful multi-disciplinary program of study. Even though civil engineering schools are conservative, our students who are the future of our construction industry must be schooled in both the conventional (open-cut) and non-conventional (trenchless methods) aspects of design and installation of pipelines, utilities, and conduits. Their decisions will affect the useful life of structures for the next 100 years.

\section{DEVELOPMENT OF CURRICULUM IN TRENCHLESS TECHNOLOGY}

According to the criteria for accrediting programs in engineering technology, the Technology Accreditation Commission of the Accreditation Board for Engineering and Technology (TAC of ABET) states: ${ }^{10}$ "The field of technology is changing rapidly. Thus, the currency of material being taught and the people teaching the material are of paramount concern to TAC of ABET. Faculty members must maintain current knowledge of their field and understanding of the tasks industry expects...(Criteria V.F.9)." 
Based on the above, the education of our students must be responsive to the needs of the industry because in the final analyses, it is the industry that hires our graduates. Teaching theory with no emphasis on real life applications of current technology is an inappropriate model for engineering education. Keeping that in mind, the authors have utilized the existing sequence of courses in their construction curriculum to deliver a state-of-the-art education in trenchless technology.

\section{SEQUENCE OF COURSES}

The step-by-step approach to educating students in the broad spectrum of construction with applications of trenchless technology brought in at the pre-determined points in the curriculum essentially follows the sequence shown in Table 1. Academic instruction in trenchless technology techniques is highly applied in nature. It bears on the strength of classical engineering sciences and theories; hence its fundamentals, as well as applications, are interspersed in statics, dynamics, material engineering, pipeline hydraulics, soil mechanics, etc. Students in their design courses on reinforced concrete, steel, and wood come to appreciate the importance of durability and serviceability of underground and above-ground infrastructure.

Table 1 - Sequence of Courses

\begin{tabular}{|c|c|c|c|c|}
\hline Year & Course Title & Course Description & $\begin{array}{c}\text { Trenchless Technology } \\
\text { Applications }\end{array}$ & $\begin{array}{l}\text { Semester } \\
\text { Cr. Hrs. }\end{array}$ \\
\hline 1 & $\begin{array}{l}\text { Methods \& } \\
\text { Materials of } \\
\text { Construction }\end{array}$ & $\begin{array}{l}\text { Introductory study of materials used in } \\
\text { the construction industry. Construction } \\
\text { methods and techniques including } \\
\text { procedures of inspection. }\end{array}$ & $\begin{array}{l}\text { New pipe materials, } \\
\text { introduction to trenchless } \\
\text { technology methods. }\end{array}$ & 3 \\
\hline 2 & Surveying I & $\begin{array}{l}\text { Introduction to basic principles of } \\
\text { plane surveying with applications to } \\
\text { engineering and construction problems. }\end{array}$ & $\begin{array}{l}\text { Use of lasers, line \& grade } \\
\text { determination in pipeline } \\
\text { construction, use of } \\
\text { surveying and locating } \\
\text { equipment. }\end{array}$ & 4 \\
\hline 3 & $\begin{array}{l}\text { Fluids and } \\
\text { Hydraulics }\end{array}$ & $\begin{array}{l}\text { Introduction to fluid mechanics } \\
\text { including fluid statics and elementary } \\
\text { fluid dynamics. }\end{array}$ & $\begin{array}{l}\text { Hydraulic systems, I/I } \\
\text { studies and flow calculation } \\
\text { for pipeline rehabilitation } \\
\text { projects. }\end{array}$ & 3 \\
\hline 3 & $\begin{array}{l}\text { Construction } \\
\text { Estimating }\end{array}$ & $\begin{array}{l}\text { Quantity take-offs and cost estimating } \\
\text { for conventional versus non- } \\
\text { conventional construction. }\end{array}$ & $\begin{array}{l}\text { Estimating quantities and } \\
\text { cost of trenchless projects. }\end{array}$ & 3 \\
\hline
\end{tabular}




\begin{tabular}{|c|c|c|c|c|}
\hline 3 & $\begin{array}{l}\text { Construction } \\
\text { Management }\end{array}$ & $\begin{array}{l}\text { Specifications and contract } \\
\text { administration, bonding and insurance. }\end{array}$ & $\begin{array}{l}\text { Contract specifications and } \\
\text { administration for trenchless } \\
\text { projects. }\end{array}$ & 3 \\
\hline 4 & $\begin{array}{l}\text { Soil Mechanics and } \\
\text { Foundations }\end{array}$ & $\begin{array}{l}\text { Studies properties of soil with } \\
\text { applications in design and } \\
\text { construction. }\end{array}$ & $\begin{array}{l}\text { Soil/pipe/machine } \\
\text { interactions and use of } \\
\text { slurries in trenchless } \\
\text { projects. }\end{array}$ & 4 \\
\hline 4 & $\begin{array}{l}\text { Construction } \\
\text { Planning and } \\
\text { Scheduling }\end{array}$ & $\begin{array}{l}\text { Importance of building the project } \\
\text { within budget and time. }\end{array}$ & $\begin{array}{l}\text { Management of time \& } \\
\text { budget in trenchless } \\
\text { projects, effects of direct, } \\
\text { indirect and social costs on } \\
\text { the total cost of project. }\end{array}$ & 3 \\
\hline 4 & $\begin{array}{l}\text { Introduction to } \\
\text { Trenchless } \\
\text { Technology }\end{array}$ & $\begin{array}{l}\text { An introduction to design \& } \\
\text { construction of trenchless projects } \\
\text { utilizing horizontal directional drilling } \\
\text { (Mini, Midi, and Maxi), pipeline } \\
\text { rehabilitation, microtunneling, pipe } \\
\text { jacking, auger boring, and construction } \\
\text { of temporary structures. }\end{array}$ & $\begin{array}{l}\text { A more detailed analyses of } \\
\text { trenchless design and } \\
\text { construction. }\end{array}$ & 3 \\
\hline 4 & $\begin{array}{l}\text { Topics in Heavy } \\
\text { Construction }\end{array}$ & $\begin{array}{l}\text { Underground construction is discussed } \\
\text { in length. }\end{array}$ & $\begin{array}{l}\text { Capstone course with } \\
\text { trenchless applications. }\end{array}$ & 3 \\
\hline
\end{tabular}

\section{THE CAPSTONE COURSE IN}

\section{CONSTRUCTION TECHNOLOGY}

Advances in trenchless technology during the last 10-15 years have contributed significantly to the sophistication of the contemporary construction industry. This affects undergraduate education significantly. The thrust of education must be to provide engineers and construction managers with a strong knowledge-base of both conventional and non-conventional methods of construction. Owners and engineers should feel comfortable in trying out the newer methods of construction, and their willingness to utilize the latest advances in technology should be reflected in the project specifications. Contractors should be encouraged to submit bids that utilize conventional and non-conventional approaches for underground infrastructure construction. This can all be feasible only if the decision makers have the appropriate background and training in the appropriate disciplines of education.

Undergraduate education should include the latest available technologies and the relevant code requirements. Where there are code shortcomings, they ought to be brought to light. At the present time, there is

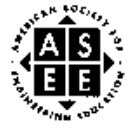

1996 ASEE Annual Conference Proceedings 
a dearth of classroom texts on trenchless technology. It is therefore important that we utilize the available resources from industry, such as case histories of actual projects, to teach our students.

\section{CONCLUSIONS}

In 1950's and 1960's, construction of highways and bridges was of strategic importance to our nation. In 1970 's, trend shifted to improvement of sewers and wastewater treatment plants. Roughly about the same time, mass transit and subway tunnels attracted the nation's attention. Now it is time for utilization of trenchless technology in our underground infrastructure. There is a need for development of instructional and resource materials for delivering trenchless technology education at the undergraduate level. There is a need for building alliances between schools and industry to reduce duplication in training and education. Recognizing the restraints of curriculum developments at the level of undergraduate engineering and technology education, the authors encourage the modification of existing curriculums to include the subject matter of trenchless technology applications. Case histories involving new installation methods, such as horizontal directional drilling, pipe jacking/microtunneling, and a variety of pipeline rehabilitation methods should be discussed within the realm of undergraduate education to give the students a broad exposure to various techniques available to solve underground infrastructure problems. The authors encourage schools of civil and construction engineering to develop a course in trenchless technology similar to the one they have developed at their own institution. According to Dr. Ray Sterling, Director of the Trenchless Technology Center at Louisiana Tech University, "The infrastructure provided by a society depends to at a large extent on a basic system of community values." 11 As educators, it is imperative that we play a significant role in shaping those community values by developing sound models of engineering and technology education that are not only pragmatic in nature but also ensure building of an economically sound infrastructure. The future for trenchless technology is bright; we need only to steer gently and with resolve.

\section{REFERENCES}

1. Schrock, B.J. (1992). "Pipeline Rehabilitation Market Overview," Trenchless Technology, November/December 1992, pp. 41-43.

2. Kramer, S., McDonald, W. and Thomson, J. (1992). "An Introduction to Trenchless Technology," Chapman $\&$ Hall, New York, NY.

3. Iseley, D.T. and Najafi, M., Editors (1995). "Trenchless Pipeline Rehabilitation," The National Utility Contractors Association (NUCA), Arlington, VA.

4. Rogers, C.D.F. (1995). "Comparison of Ground Disturbance for Trenching and Pipe Bursting Operations," NO-DIG Engineering, Vol. 2, No. 4., Winter 1995, p. 8. 
5. Hadala, P.F. (1995). "Training and Education in Trenchless Technology: Trenchless Technology Education Trends," NO-DIG Engineering, Vol. 2, No. 3, March 1995.

6. Iseley, D.T. and Tanwani, R., Editors (1992). "Trenchless Excavation Construction Equipment and Methods," The National Utility Contractors Association (NUCA), Arlington, VA.

7. Najafi, M., Iseley, D.T. and Varma, V.K. (1994). "LLB Microtunneling Method," Proceedings of Microtunneling Short Course Conference, Colorado School of Mines, Golden, CO.

8. Najafi, M. and Varma, V.K. (1995). "Trenchless Pipeline Rehabilitation Systems," Proceedings of the Second International Conference in Advances in Underground Pipeline Engineering, June 25-27, 1995, Bellevue, Washington, American Society of Civil Engineers (ASCE), New York, NY.

9. Sprague, S., Varma, V.K., and Najafi, M. (1995). "A Case Study: Mini-HDD Boring for 102 River Crossing in St. Joseph, Missouri," Proceedings of New Advances in Trenchless Technology Seminar, Sponsored by the Department of Engineering Technology at Missouri Western State College, February 5-8, 1995, St. Joseph, MO.

10. Criteria for Accrediting Programs in Engineering Technology, (1994-95). Technology Accreditation Commission, Accreditation Board for Engineering Technology, Inc., (TAC/ABET), New York, NY.

11. Sterling, R. (1995). "The Development of Infrastructure and Trenchless Technology," Trenchless Technology, Vol. 4, Number 10, October 1995.

VIRENDRA K. VARMA, Ph.D., P.E., F.ASCE is a professor of construction engineering technology at Missouri Western State College. He is a registered civil and structural engineer. He has over 25 years of engineering experience in project design and management, and has published in a variety of journals. He is a two-time recipient of Excellence-in-Teaching Award at Missouri Western.

MOHAMMAD NAJAFI, Ph.D., P.E. is an assistant professor of construction engineering technology at Missouri Western State College. He is a registered professional engineer. He has over 12 years of engineering experience as project engineer and manager, and has published in a variety of journals. He is the Technical Editor of NO-DIG Engineering Journal. 